«Keruen» scientific journal

M.O.Auezov Institute of Literature and Art

ISSN 2078-8134

Volume 4, Number 69 (2020)

https://doi.org/10.53871/2078-8134.2020.4-09

IRSTI 17.01.17

\author{
A.K. Mashakova \\ M.O. Auezov Institute of Literature and Art, \\ Almaty, Kazakhstan, \\ e-mail: a_mashakova@mail.ru \\ ORCID: 0000-0001-5700-457X
}

\title{
FOREIGN PERCEPTION OF THE LITERATURE OF KAZAKHSTAN
}

Abstract. For profound and overall study of history of contemporary literature of Kazakh people it is necessary to consider achievements of literature of other nations and perception of literature of native literature within the context of world community. Actuality of the proposed issue causes objective necessity of studying reception of creation of Kazakh writers and poets in foreign countries, because at present best patterns of Kazakh literature have been translated into languages of many countries of the world. In this article the author discusses the special features and originality of foreign perception of the literature of Kazakhstan during Independence period. Literary translation plays a major role in this process. The number of translations and foreign feedbacks, reviews and studies is an important index for determining the international literary scale of a writer or poet.

Key words: literature, Kazakhstan, translation, foreign languages, publication, perception, source, international resonance.

Introduction. Kazakhstan has participated in the spiritual and intellectual communication with the peoples of different countries for a long time. Foreign literary critics, scholars, literary critics, writers and poets, translators do important contribution to the study of the Kazakh literature along with Kazakhstan scientists. Since independence period, scales of studies of creativity of Kazakhstan writers in the CIS and far abroad have increased. In the conditions when literature in the modern world is one of the means of spiritual communication and mutual understanding of different peoples of the world, the study of foreign perception of Kazakh literature is the relevant objective of Kazakhstan literary criticism.

The research idea is to show the extent of the international spread of interest in the literature of Kazakhstan. The aim is to present the foreign perception of the literature of Kazakhstan, consider the extensive material on the following aspects: artistic translation and publication of works by Kazakhstan authors in the CIS and far abroad.

In this article, the issue of perception is considered from the point of view of classical history of national literatures. The work of foreign literature, when appears in a new context and becomes a part of it, participates in the development of perceiving literature, along with the works created inside it. Therefore, any work that has been the object of perception of foreign literature and has been reinterpreted in terms of a new tradition is an integral component of its history. For profound and overall study of history of contemporary literature of Kazakh people it is necessary to consider achievements of literature of other nations and perception of literature of native literature within the context of world community.

Methods. Used research methods: historical-literary, analytical, textual, eureka-hermeneutic, comparative-comparative, historical-typological. Comparative-comparative method reveals the nature and originality of artistic translations, the historical-typological method makes it possible to 
reveal the similarity of phenomena of different origin, the same conditions of genesis and the development of national literatures.

Comparative study of the literary process incorporates the main approaches inherent in literary science: historical-genetic, historical-functional, systemic, psychological. The historicalgenetic approach is focused on explaining the similarity of phenomena as a result of their relation by origin.

This study involves the use of a variety of methodological and theoretical approaches, intensification of interdisciplinary research. The basic methodological directions in this work are the basic principles of dialectical, ontological, structural-formalistic, and also discursive-receptive poetics.

The study of one national literature through the perception of the another one is of undoubted scientific interest in terms of comparative studies. Foreign literary scholars R.J.Clements (Clements, 1978), D.Durishin (Durishin, 1979), H.R.Yauss (Yauss, 1982), V.Izer (Izer, 1999), P.Toper (Toper, 2000), as well as Russian scientists G.D.Gachev (Гачев, 2008), E.I.Lyapushkina (Lyapushkina, 2002) and Ukrainian researcher R.T.Gromyak (Громяк, 2005) were involved in the research works on this topic. The basic thesis in studying foreign perception of literature is the thesis of the Russian researcher on comparative studies L.V.Chernets: «A foreign critic is the first representative of the progeny for the writer» (Chernets, 2003: 199). Y.Borev believes, «...the comparison of the variants, the study of the drafts, preparatory records establishes the direction of development of the author's thought and turns all these materials into the means of interpretation of the work» (Borev, 2004: 33). The national researcher in comparative studies M. Madanova calls the «complex and multifaceted study of the dynamics of introduction of national literature into the world artistic process" as a priority task of literary comparative studies» (Madanova, 2003: 23).

In the course of this study attention is paid to following articles: «The effects of formal training on literary reception» (Dixon, Bortolussi, 1996), «Artistic Communication and Dialogue of Cultures in Transboundary Context: "the Kazakh text" as a Subject of Imagological Research» (Gabdullina, Dyusekenev, 2018), «Archetypes of Kazakh and Japanese Cultures» (Bekebassova, 2019).

Results. Literary scholars from the M.O.Auezov Institute of Literature and Art make a significant contribution to the study of literary connections, determination of the place of Kazakh literature in the context of the world's artistic process, comprehension of the role and importance of literature in the dialogue between cultures. Institute scientists have established international relations with domestic and foreign higher educational institutions, scientific centers: Kazan Federal University (Kazan), Abai Center of the Baku State University (Baku), Tashkent State Pedagogical University (Tashkent), the Institute of Literary Studies of the National Academy of Sciences of Belarus (Minsk), The Center of the Kazakh language, history and culture named after Abai at Belarusian National University (Minsk), the University of Mugla (Mugla, Turkey). They have various scientific and creative contacts with foreign researchers - Hatip Minnegulov (Russia), Firuza Agayeva (Azerbaijan), Abdulla Rustamov (Uzbekistan), Mikola Metlitski and Ales Karlyukevich (Belarus), Ali Abbas Chinar (Turkey), Lily Zheng (China) and others.

For a number of years they have been engaged in scientific activities in the framework of the fundamental and applied research program of the Ministry of Education and Science of the Republic of Kazakhstan. As a result, they prepared and published joint monographs: «Literary and Artistic Dialogue», «International Relations of Kazakh Literature of the Independence Period», «Integration Processes and Kazakh Literature», «Kazakh-American literary relations», «World Literary Process of the XXI Century», «Abai Kunanbayev in World Literary Studies». The collections «World of Auezov», «World of Nurpeissov», «World of Olzhas Suleimenov», «Creativity of Abai Kunanbayev in a foreign reception» in the series «International relations of Kazakh Literature» have published. These collections include foreign sources on the creativity of Kazakh writers and poets, translated into Russian from various foreign languages. There are no analogues of these books in Kazakhstan. These scientific works are widely spread in the world. Thus, the collection «Creativity of Abai Kunanbayev in foreign reception» has been transferred to 
the libraries of Korea, Iran, Poland, Germany, Russia, Belarus, Azerbaijan, Georgia, Tatarstan, Uzbekistan. In 2017 the collection was transferred to the National Library of Belarus, the Institute of Literary Studies of the National Academy of Sciences of Belarus, the Center for Kazakh Language, History and Culture named after Abai in the Belarusian National University.

Currently, it is planned to prepare the collection «Foreign Perception of the Literature of Kazakhstan», which will include publications by foreign authors related to the creative writings of Makhambet Utemissov, Zhambyl Zhabayev, Sabit Mukanov, Gabit Musrepov, Anuar Alimzhanov, Ilyas Esenberlin, Maurice Simashko, Dmitry Snegin, Abish Kekilbayev, Mukagali Makatayev, Satimzhan Sanbayev, Sabit Dosanov, Gerold Belger and other famous writers and poets of Kazakhstan. Their works have been translated into several languages of the peoples of the CIS and other foreign countries. The idea to collect materials on foreign perception of the above-mentioned writers of Kazakhstan in one collection arose due to the fact that there are not so many translations and, correspondingly, few foreign responses to their creative writings in comparison with the works of Abai Kunanbayev, Mukhtar Auezov, Abdizhamil Nurpeissov and Olzhas Suleimenov, whose works have been translated into many foreign languages, and received so many responses from foreign writers, poets and literary critics that they were published in separate collections. Despite the smaller scale of foreign perception of the above-mentioned writers, high appreciation of their creativity by professional readers of the CIS and foreign countries is of great value for international recognition of the literature of Kazakhstan. Currently, there is extensive material on the Foreign Perception of the Literature of Kazakhstan, which has not been translated and published so far.

The scientific novelty lies in the fact is that foreign publications related to the creative writings of a number of writers and poets of Kazakhstan will be collected and generalized in translation into Kazakh and Russian languages for the first time. By present period, similar works have been carried out, basically, based on foreign perception of one writer or poet. In addition, the novelty will be the inclusion of not only Kazakh writers, but also representatives of Russian, German and other ethnic groups of Kazakhstan. New materials from foreign languages will be introduced into scientific circulation. The names of new foreign researchers of national literature who have not been know yet will be presented.

The publication of the collection in the Kazakh language complies with main provisions set forth in the N.Nazarbayev's article «Look into the Future: Modernization of Public Consciousness». Offering the agenda for the coming years, he calls the project «New Humanitarian Knowledge. 100 new textbooks in Kazakh» on public and humanitarian knowledge as a priority area, which will provide «the opportunity for our youth to learn from the best world models» (Nazarbayev, 2017: 2). The new collection is intended to familiarize Kazakh students of philological faculties of higher educational institutions with literary critical articles of foreign professional readers - literary scholars, literary critics, writers and poets analyzing the work of prose writers and poets of Kazakhstan.

The publication of the collection in Russian will contribute to the implementation of another project «Modern Kazakhstani culture in the global world», which has been proposed by N.Nazarbayev. As we know, Russian is one of the six languages of the UN. In our country, it functions as a language of interethnic communication. During the discussion of the program article «Look into the Future: Modernization of Public Consciousness» at a round table discussion which was organized by the Embassy of Kazakhstan in Russia, A.Vassiliev, Senior Researcher of the Center for Central Asia, the Caucasus, the Urals and Volga Region Studies, the Institute of Oriental Studies, Russian Academy of Sciences, noted: «The Russian language will be used as a means of transmission of the economic and cultural achievements of Kazakhstan to the international arena» (Nazarbayev, 2017). In the planned collection - as a means of transmission of the achievements of the literature of Kazakhstan in the global world.

Discussion. The development of Kazakh literature is currently taking place in the context of globalization and integration of the independent Republic of Kazakhstan into the world community. The entry of Kazakh literature into the world artistic process is conditioned by such factor as artistic translation. The process of translating Kazakh literature into the languages of the world's peoples 
can be divided into two periods. The Soviet period can be called a favorable period in the history of artistic translation of Kazakhstan. Most of foreign translations have been done in the socialist countries. Thus, the books of many Kazakhstan authors: A.Alimzhanov, T.Akhtanov, A.Kekilbaev, S.Sanbayev, M.Simashko, D.Doszhanov were translated into German and published in the GDR. Among Western European countries, the significant work in the field of translation of Kazakh literature was done in France. In this country in the middle of the 20th century the works of the most famous Kazakhstan writers have been translated into French earlier than in other Western European languages. For example, the publishing house «Gallimard» published «The Stories of Black and Red Sands» and the novel «Mazdak» by M. Simashko.

The artistic translation of Kazakhstan writers and poets into the world languages during the first years of the independence of Kazakhstan was done rarely, but over time the situation changed for the better. In 1993, a collection of short stories by D.Doszhanov in Spanish has been published in Barcelona. In 1995, the «Hatyngol Ballad» by A.Kekilbayev was published in Mongolia. In 1996, in Canada and the UK, the poetic collection «Time of Silence» by B.Kanapyanov was published in English. In 1998, the book «From Baikal to the Balkans» by R.Berdibay was translated in Turkey. In 1999, the book «End of the Legend» by A.Kekilbayev was published in Hungary, M.Shakhanov's «The Misconception of Civilization» was published in Turkey, and in Germany and Switzerland there was a presentation of this book in the German language.

In the XXI century the intensification of the process of artistic translation of the literature of Kazakhstan abroad has been observed. In 2006, the novel «The Minaret, or the End of a Legend» by A.Kekilbayev was published in Germany, and I.Esenberlin's book «The Nomads» was published in Bulgaria. In 2007, presentation of the book «White Aruana» by S.Dosanov took place in France, in 2008 - presentation of the book «Wind of the Steppes» with selected poems of S.Sariev and N.Orazalin, in Germany the novel «Buran» by T.Akhtanov was published. In 2009, Berlin hosted the presentation of the novel by G.Belger «House of the Wanderer». In 2013, the Anthology of Kazakh literature «The Stories of the Great Steppe» with works by G.Musrepov, A.Kekilbayev, M.Makatayev, F.Ongarsynova, B.Kanapyanov, D.Amantai, S.Sariev and others was published in the US. In 2013, D.Amantai's book «At the Top of Karkaraly» was published in French, Turkish and Mongolian. In 2014, a collection of D.Isabekov's works was presented in England, a book «Berge sind Legende» with selected poems of M.Makatayev was published in Germany. In 2015, in the US the Anthology of Kazakh literature «Summer Evening, Prairie Night, Land of Golden Wheat», the story of B.Sokpakbayev «My name is Koja» and M.Makatayev's poetic collection «Selected poetry of Mukaghali» have been published. Literary contacts established during the Soviet period with the CIS countries are continuously developing.

Thanks to the process of artistic translation of the literature of Kazakhstan in the CIS and foreign countries, the material related to its foreign perception is constantly being supplemented with new sources. In this regard, there is a need to present the full scale of international resonance of the works of Kazakhstan writers and poets to the wide range of readers.

One can name a number of countries that during the independence period show the greatest interest in Kazakh literature. Among European countries - France, Germany and Hungary, and among countries of the foreign East - Turkey, India, Pakistan, Iran, China, Mongolia, interest in Kazakh literature is growing in the USA.

The research on foreign perception of the literature of Kazakhstan allows us to determine the periodisation of this process. It can be divided into two stages: the first stage corresponds to the Soviet period of development of Kazakh literature, and the second stage begins with Kazakhstan's independence and continues to present day. The nature of the perception of our literature abroad during the Soviet period and the period of independence is different. In the Soviet period, the process of perception was descriptive and introductory in nature. Because, previously, not only Kazakh literature, but also the Kazakh people themselves were not known abroad, therefore, in these reviews and critical articles, it was possible to familiarize foreign readers with the Kazakh nation, the customs, originality and specificity through the works of the Kazakh writers and poets. In the period of independence, the process of the in-depth analysis of the works increases, this 
expresses the evolutionary nature of the process of foreign perception. Although, of course, the foreign perception of Kazakh literature sometimes is still descriptive, the in-depth analysis prevails. The main feature is the appearance of scientific monographs on Kazakh literature in foreign countries.

Conclusion. Perception of the creative work by national and foreign public, certainly has different character. Foreign sources of perception have great importance in the history of national literatures, because they are, as a rule, the evidence of a new, in most cases objective, and sometimes unexpected, unexpected look at ordinary phenomena and facts. Study of one national literature through the perception of the other is of obvious scientific interest. Professional approach of the reader to literary perception, his/her knowledge and experience are also important. Important is the revealing the role of the critic of the foreign country in the evaluation of national literature, as he differently evaluates the well-known facts in the writer's homeland, perceives the things reflected in the artistic work from a different vision.

\author{
А.К. Машақова \\ М.О.Әуезов ат. Әдебиет және өнер институты, \\ Алматы қ., Қазақстан, \\ e-mail: a_mashakova@mail.ru \\ ORCID iD: 0000-0001-5700-457X \\ Scopus iD: 57196947633 \\ WoS iD: Y-5258-2019
}

\title{
ҚАЗАҚСТАН ӘДЕБИЕТІНІН ШЕТ ЕЛДЕРДЕ ҚАБЫЛДАНУЫ
}

Аңдатпа. Қазақ халқының қазіргі әдебиет тарихын терең де жан-жақты зерттеу үшін өзге халықтар әдебиетінің жетістіктеріне көніл бөлу қажет және төл әдебиетіміздің әлемдік әдеби қоғамдастық контекстінде қабылдануын ескеру керек. Ұсынылған мәселенің өзектілігі қазақ жазушылары мен ақындары шығармашылығының шетелдік қабылдануын зерттеудің қажеттілігінен келіп туындайды, себебі, қазірде қазақ әдебиетінің ең озық үлгілері көптеген әлем тілдеріне аударылған. Мақалада автор тәуелсіздік кезеңіндегі шетел қабылдауындағы Қазақстан әдебиетінің өзіндік сипаты мен ерекшеліктерді қарастырады. Бұл үдерісте көркем аударма үлкен рөл атқарады. Аудармалар саны, шетелдік шолулар мен зерттеулер жазушының немесе ақынның халықаралық әдеби ауқымын анықтайтын маңызды көрсеткіш болып табылады.

Кілт сөздер: әдебиет, Қазақстан, аударма, шетел тілдері, басып шығару, қабылдануы, көз, халықаралық қарсы алу.

\author{
А.К. Машакова \\ Институт литературы и искусства им. М.О.Ауэзова, \\ г. Алматы, Казахстан, \\ e-mail: a_mashakova@mail.ru \\ ORCID iD: 0000-0001-5700-457X \\ Scopus iD: 57196947633 \\ WoS iD: Y-5258-2019
}

\section{ЗАРУБЕЖНОЕ ВОСПРИЯТИЕ ЛИТЕРАТУРЫ КАЗАХСТАНА}

Аннотация. Для глубокого и всестороннего исследования истории литературы казахского народа необходимо принимать во внимание достижения литератур других народов и учитывать восприятие отечественной литературы своего народа в контексте мирового литературного сообщества. Актуальность заявленной проблемы вызывает объективную необходимость изучения восприятия творчества казахских писателей и поэтов 
в зарубежных странах, поскольку к настоящему моменту лучшие образцы казахской литературы переведены на языки народов многих стран мира. В данной статье автор рассматривает особенности и своеобразие зарубежного восприятия казахстанской литературы периода независимости. Большую роль в этом процессе играет художественный перевод. Количество переводов и зарубежных отзывов, рецензий и исследований является важным индексом для определения международного литературного масштаба писателя или поэта.

Ключевые слова: литература, Казахстан, перевод, иностранные языки, издание, восприятие, источник, международный резонанс.

\section{REFERENCES}

[1] Bekebassova A.N. (2019). Archetypes of Kazakh and Japanese Cultures. News of NAS RK, 6, 87-93 (eng.).

[2] Borev Y. (2004). Interpretation of artistic work. Problems of modern comparative literature (28-37). Moscow: Publ. House of the Institute of World Literature RAS (rus.).

[3] Chernets L.V. (2003). Foreign critic - is a first representative of generation for writer. Comparative Literature: a theoretical and historical aspects (199-207). Moscow: Moscow State University Press (rus.).

[4] Clements R.J. (1978). Comparative Literature as Academic Discipline. New York: Modern Language Association of America (eng.).

[5]Dixon P., Bortolussi M. (1996). The effects of formal training on literary reception. Poetics (Scopus), Vol. 23, Issue 6, 471-487 (eng.).

[6] Dyurishin D. (1979). The theory of comparative study of literature. Moscow: Progress (rus.).

[7] Gabdullina V.I., Dyusekenev D.N (2018). Artistic Communication and Dialogue of Cultures in Transboundary Context: «the Kazakh text» as a Subject of Imagological Research. World of science, culture, education (Russian Science Citation Index), 1, 366369 (rus.).

[8] Gatchev G.D. (2008). The mentality of the peoples of the world. Moscow: Algoritm (rus.)

[9] Gromyak R.T. (2005). Methodology for the implementation of the receptive approach to literary phenomena in comparative studies. Literary Comparative, 1, 64-73 (ukr.).

[10] Iser V. (1999). Receptive aesthetics. Hermeneutics and translatability. Academic Notebooks, 6, 59-96 (rus.).

[11] Jauss H.R. (1982). Toward an Aesthetic of Reception. Minneapolis: University of Minnesota Press (eng.).

[12] Look into the future of Kazakhstan (2017). VESTI.RU. URL: http://www.vesti.ru/doc.html?id=2890065.

[13] Lyapushkina E.I. (2002). Introduction to hermeneutics. St. Petersburg: Publishing house of St. Petersburg University (rus.).

[14] Madanova M. (2003). Introduction to comparative literature. Almaty (rus.).

[15] Nazarbayev N.A. (2017). Look into the Future: Modernization of Public Consciousness. Kasachstanskaja Prawda, 71, 1-2.

[16] Topper P.M. (2000). Translation in the system of comparative literature. Moscow: Nasledie (rus.).

\section{ӘДЕБИЕТ}

[1] Бекебасова А.Н. (2019). Қазақ және япония мәдениетінің архетиптері. ҚР ҰҒА Хабарлары, 6, 87-93 (ағыл.).

[2] Борев Ю. (2004). Көркем шығарманың интерпретациясы. Қазіргі салыстырмалы әдебиеттануының мәселелері (28-37). Мәскеу: РҒА ӘӘИ басп. (орыс.).

[3] Габдуллина В.И., Дюсекенев Д.Н. (2018). Шекаралас ортадағы көркемдік қатынас және мәдениеттер диалогы: «қазақ мәтіні» имагологиялық зерттеу нысаны ретінде. Ғылым, мәдениет, білім әлемі (РИНЦ), 1, 366-369 (орыс.).

[4] Гачев Г.Д. (2008). Әлем халықтарының менталитеті. Мәскеу: Алгоритм (орыс.).

[5] Громяк Р.Т. (2005). Салыстырмалы зерттеулерде әдеби құбылыстарға рецептивті көзқарасты жүзеге асыру әдістемесі. Әдеби салыстырмалы, 1, 64-73 (укр.).

[6] Диксон П., Бортолучи М. (1996). Формальді әдеби қабылдауды оқытудың әсері. Poetics (Scopus), 23 (6), $471-487$ (ағыл.).

[7] Дюришин Д. (1979). Әдебиеттерді салыстырмалы зерттеу теориясы. Мәскеу: Прогресс (орыс.).

[8] Изер В. (1999). Рецептивті эстетика. Герменевтика және аударма мүмкіндігі. Академиялық дәптерлер, 6, 59-96 (орыс.).

[9] Қазақстанның болашаққа көзқарасы (2017). BECТИ.RU. http://www.vesti.ru/doc.html?id=2890065 (opыc.).

[10] Клементс Р.Ж. (1978). Академиялық пән ретіндегі салыстырмалы әдебиет. Нью-Йорк: Қазіргі американдық тіл қауымдастығы (ағыл.).

[11] Ляпушкина Е.И. (2002). Герменевтикаға кіріспе. Санкт-Петербург: Санкт-Петербург университетінің баспасы (орыс.).

[12] Маданова М.Х. (2003). Салыстырмалы әдебиеттануға кіріспе. Алматы (орыс.).

[13] Назарбаев Н.Ә. (2017). Болашаққа бағдар: рухани жаңғыру. Казахстанская правда, 71, 1-2 (орыс.).

[14] Топер П.М. (2000). Салыстырмалы әдебиеттану жүйесіндегі аударма. Мәскеу: Наследие (орыс.).

[15] Чернец Л.В. (2003). Шетелдік сыншы - жазушы үшін кейінгі ұрпақтың алғашқы өкілі. Салыстырмалы әдебиеттану: теориялық және тарихи аспектілер (199-207). Мәскеу: ММУ басп. (орыс.)

[16] Яусс Х.Р. (1982). Рецептивтік эстетика туралы. Миннеаполис: Миннесота универ. басп. (ағыл.).

\section{ЛИТЕРАТУРА}

[1] Бекебасова А.Н. (2019). Архетипы казахской и японской культур. // Известия НАН РК. 6, 87-93 (англ.).

[2] Борев Ю. (2004). Интерпретация художественного произведения. Проблемы современного сравнительного литературоведения (28-37). - Москва: Изд. ИМЛИ РАН (рус.).

[3] Взгляд в будущее Казахстана (2017). - ВЕСТИ.RU. http://www.vesti.ru/doc.html?id=2890065 (рус.). 
[4] Габдуллина В.И., Дюсекенев Д.Н. (2018). Художественная коммуникация и диалог культур в условиях трансграничности: «казахский текст» как предмет имагологического исследования. - Мир науки, культуры, образования (РИНЦ), 1, 366-369 (рус.).

[5] Гачев Г.Д. (2008). Ментальности народов мира. Москва: Алгоритм (рус.).

[6] Громяк Р.Т. (2005). Методика реализации рецептивного подхода до литературных явлений в компаративных исследованиях. - Литературная компаративистика, 1, 64-73 (укр.).

[7] Диксон П., Бортолучи М. (1996). Эффекты формального обчения литературной рецепции. - Poetics (Scopus), 23 (6), 471 487 (англ.).

[8] Дюришин Д. (1979). Теория сравнительного изучения литературы. - Москва: Прогресс (рус.).

[9] Изер В. (1999). Рецептивная эстетика. Герменевтика и переводимость. // Академические тетради, 6, 59-96 (рус.).

[10] Клементс Дж.Р. (1978). Сравнительная литература как академическая дисциплина. Нью-Йорк: // Ассоциация современного американского языка (англ.).

[11] Ляпушкина Е.И. (2002). Введение в герменевтику. - Санкт-Петербург: Издательство Санкт-Петербургского университета (рус.).

[12] Маданова М. (2003). Введение в сравнительное литературоведение. - Алматы (рус.).

[13] Назарбаев Н.А. (2017). Взгляд в будущее: модернизация общественного сознания. - Казахстанская правда, 71, 1-2 (pyc.).

[14] Топер П.М. (2000). Перевод в системе сравнительного литературоведения. - Москва: Наследие (рус.).

[15] Чернец Л.В. (2003). Иностранный критик - это для писателя первый представитель потомства. // Сравнительное литературоведение: теоретический и исторический аспекты (199-207). - Москва: Издательство МГУ (рус.).

[15] Яусс Х.Р. (1982). О рецептивной эстетике. Миннеаполис: - Изд. Университета Миннесота (англ.). 